\title{
ANALISIS SITEM PELAYANAN ANTRIAN PADA BANK BNI SYARIAH CABANG KOTA PALU
}

\author{
ILHAM \\ HUSEIN HI. MOH SALEH \\ ASNGADI \\ Program Studi S1 Manajemen, Fakultas Ekonomi, Universitas Tadulako \\ Email:Ilhamtalitti@gmail.com; Huseinsaleh868@gmail.com; Asngady@gmail.com;
}

\begin{abstract}
ABSTRAK
This study aims to determine the performance of tellers 1 and 2 in serving deposit and withdrawal transactions. The problem (1). Identify the queuing service characteristics applied by Bank BNI Syariah Palu Branch (2). Seeing the performance of the busiest teller services 1 and 2. The busiest service performance results ( $\rho$ ) are found in teller 2, which is 0.3687 or $36.87 \%$, for teller 1 is 0.3393 or $33.93 \%$, while for the next calculation has a value of 1 customer probability 1 teller in the system (P0) 0.6605, teller 2 is 0.6311, the average number of customers in the system (Ls) for teller 1 is 0.5208 while for teller 2 is 0.5852, for average time in the system (Ws) for tellers 1 ie 0.1025 is equal to teller 2 which is 0.1025, then the average number of customers in the queue (Lq) for teller 1 is 0.1814 while for teller 2 is 0.2164 and the last is the average time in the queue (Wq) for teller 1 which is 0.0362 equal to teller 2 which is 0.04 . So the conclusion is that the service performance for these two telephones has the same level of value.
\end{abstract}

Keywords: Queue, service, performance, busy life.

\begin{abstract}
ABSTRAK
Penelitian ini bertujuan untuk mengetahui perbandingan kinerjateller 1 dan 2 dalam melayani nasabah untuk transaksi penyetoran dan penarikan tunai. Permasalahnya yaitu (1). Mengidentifikasi karakteristik pelayanan antrian yang di terapkan pada Bank BNI Syariah Cabang Palu (2). Melihat kinerja pelayanan teller tersibuk antara teller 1 dan 2 .Hasil kinerja pelayanan yang lebih sibuk $(\rho)$ terdapat di teller 2 dengan nilai tingkat kesibukan sebesar 0,3687 atau 36,87\% dan untuk teller 1 yaitu 0,3393 atau $33,93 \%$, sedangkan untuk perhitungan selanjutnya memiliki nilai yang sama antara lain: teller 1 probabiltas 0 nasabah dalam sistem (P0) 0,6605, teller 2 dengan nilai 0,6311, jumlah rata-rata nasabah dalam sistem $\left(\mathrm{L}_{\mathrm{s}}\right)$ untuk teller 1 dengan nilai 0,5208 sedangkan untuk teller 2 dengan nilai 0,5852, untuk waktu rata-rata dalam sistem $\left(\mathrm{W}_{\mathrm{s}}\right)$ untuk teller 1 dengan nilai 0,1025 sama nilainya dengan teller 2 yaitu 0,1025 , selanjutnya jumlah rata-rata nasabah dalam antrian $\left(\mathrm{L}_{\mathrm{q}}\right)$ untuk teller 1 dengan nilai 0,1814 sedangkan untuk teller 2 dengan nilai 0,2164 dan yang terakhir adalah waktu ratarata dalam antrian $\left(\mathrm{W}_{\mathrm{q}}\right)$ untuk teller 1 dengan nilai 0,0362 sama nilainya dengan teller 2 yaitu 0,04. Jadi dapat disimpulkan bahwa kinerja pelayanan untuk kedua teler ini memliki tingkat nilai yang sama.
\end{abstract}

Kata Kunci: Antrian, pelayanan, kinerja, kesibukan.

\section{PENDAHULUAN}

Dunia perbankan sudah menjadi kebutuhan masyarakat pada umumnya, karna banyak manfaat yang diperoleh masyarakat dalam menggunakan produk-produk perbankan diantaranya tabungan, deposito, reksa dana dan lain-lain. Nasabah mengharapkan dana mereka dapat aman dan dikelola dengan baik dengan pengelolah perbankan. Persaingan antar bank juga tidak bisa dihindari sehingga masing-masing bank berlomba-lomba untuk berinovasi dalam meningkatkan kualitas layanan.

Salah satu bagian yang paling penting adalah pelayanan waktu di teller, lamanya antrian akan mengakibatkan kualitas layanan kurang memuaskan. Peranan teller dalam suatu perbankan berperan besar karena teller beriteraksi lansung pada nasabah yang hendak melakukan transaksi pada bank. Teller adalah petugas bank yang secara lansung bertanggung jawab untuk melakukan serangkaian 
proses transaksi seperti tabungan, deposito, reksa dana dan lain-lain serta memberikan kepuasan pelayanan berupa jasa perbankan kepada para nasabah.

Nasabah yang meninggalkan kursi antrian/garis antrian akibat lamanya waktu menunggu gilirannya untuk melakukan transaksi merupakan kasus yang sering terjadi pada bagian teller. Masalah antrian sebenarnya bukan hanya pada bank saja, namun terjadi pula pada kasus pembelian tiket pemutaran bioskop, antrian pada Stasiun Pengisian Bahan Bakar Umum atau SPBU, supermarket, bengkel dan lain-lain.

Bank Negara Indonesia Syariah atau biasa disingkat Bank BNI Syariah merupakan cabang Bank Syarish satu-satunya di Kota Palu Sulawesi Tengah. BNI Syariah cabang kota palu ini beroperasi setiap Hari Senin - Kamis dimulai dari pukul 08:00 - 12:00 dan pukul 13:00 - 16:00 WITA dan hari Jumat dimulai pukul 07.30 - 16.00. BNI Syariah ini menyediakan bebagai pelayanan kepada nasabah khususnya pada bagian teller, seperti transfer, penarikan, setor tunai dan pembayaran SPP untuk mahasiswa dari Universitas Alkhairat, Universitas Bina Mulya, Universitas Sekolah Tinggi Ilmu Kesehatan dan Universitas Muhammadiah Palu.

Meskipun Bank telah menggunakan 2 teller dalam pelayanannya, nasabah masih merasa pelayanan yang diberikan kurang memuaskan karena waktu yang cukup lama. Bahkan terdapat pula nasabah yang berdiri akibat tidak mendapatkan tempat duduk, hal ini diduga terjadi disebabkan oleh sistem antrian yang belum diterapkan maksimal terlebih lagi jika bertepatan dengan pembayaran UKT (Uang Kuliah Tunggal) telah tiba.

Jumlah kedatangan nasabah yang datang ke bank yang tidak dapat diprediksi sebelumnya mengakibatkan jumlah antrian di dalam ruangan menjadi penuh, bahkan biasanya nasabah yang tidak mendapat kursi antrian harus berdiri untuk menunggu pemanggilan nomor antriannya terlebih lagi apabila saat pembayaran uang SPP telah tiba. Namun demikian pihak bank yang selalu siap siaga dengan nasabahnya dengan cara security akan memberitahukan kepada nasabah yang berada didalam ruangan bahwa nomor antrian mereka telah dipanggil dengan bantuan security yang ada tepat di dalam bank. Keadaan yang demikian harus diperhatikan oleh pihak manajemen bank karena apabila nasabah yang sudah terlalu lama mengantri dan mengeluh kepada bank karena lama mengantrinya dapat menimbulkan ketidakpuasan kepada pelayanan yang diberikan oleh bank terutama dari pihak teller, oleh karena itu pihak bank harus mampu melihat kinerja pelayanan teller tersibuk antara kedua teller dengan tujuan untuk melihat kinerja yang lebih optimal di antara keduanya dan melihat karakteristik antrian dan pelayanan yang pada bank guna untuk lebih memaksimalkan kinerja yang ada.

\section{KAJIAN LITERATUR DAN PENGEMBANGAN HIPOTESIS}

Manajemen Operasional adalahsetiap kegiatan yang menghasilkan produk dan jasa pada organisasi bisnis membutuhkan teknik dan metode tertentu agar proses produksi maupun pelayanan dapat berjalan efisien dan efektif. Disiplin ilmu yang mempelajari segala macam hal mengenai proses produksi dan pelayanan ini dikenal dengan istilah manajemen produksi atau operasi. Menurut Kosasih (2009:2) operasi merupakan kegiatan yang lebih luas dari produksi, operasi tidak hanya kegiatan menciptakan barang saja tapi meliputi kegiatan administrasi, perdagangan, perbankan, dan kegiatan jasa lainnya termasuk kedokteran.

Definisi manajemen operasi menurut beberapa ahli diantaranya: Manajemen operasi (operation management -OM) menurut Heizer dan Render (2006:4) adalah serangkaian aktivitas yang menghasilkan nilai dalam bentuk barang dan jasa dengan mengubah input menjadi output. Definisi lain menurut Haming dan Nurnajamuddin (2011:25) manajemen operasi adalah kegiatan yang berhubungan dengan perencanaan, pengkoordinasian, penggerakan, dan pengendalian aktivitas organisasi yang berhubungan dengan proses pengolahan masukan menjadi keluaran dengan nilai tambah yang lebih besar. Sedangkan menurut Yamit (2003:5) manajemen operasi adalah kegiatan untuk mengolah input melalui proses transformasi atau pengubahan atau konversi sedemikian rupa sehingga menjadi output yang dapat berupa barang dan jasa. Berdasarkan pendapat-pendapat di atas dapat disimpulkan bahwa manajemen operasi adalah rangkaian aktivitas manajemen untuk mengelola input menjadi output berupa produk (barang atau jasa) yang memiliki nilai tambah. 
Jasa adalah output dari kegiatan manajemen operasional disebut dengan produk. Produk dapat berupa barang atau jasa yang dapat diperjualbelikan. Produk dapat diklasifikasikan dengan berbagai cara. Salah satunya adalah dengan menggolongkan apakah produk tersebut berwujud atau tidak berwujud. Berdasarkan kriteria tersebut, produk dapat diklasifikasikan sebagai barang yang tahan lama, barang tidak tahan lama, dan jasa.

Kotler and Keller (2009:36) mendefinisikan jasa sebagai tindakan atau kegiatan yang dapat ditawarkan kepada pihak lain, pada dasarnya tidak berwujud dan tidak mengakibatkan kepemilikan apapun, produksi jasa dapat terkait dengan produk fisik atau tidak.

Bank merupakan salah satu lembaga keuangan yang menjadi tempat bagi perusahaan dan badan usaha pemerintah dan swasta maupun perorangan dalam melakukan aktivitas keuangan yaitu menghimpun dana, perkreditan dan berbagai transaksi jasa. Menurut Undang-Undang Perbankan Nomor 10 Tahun 1998 yang dimaksud dengan bank adalah badan usaha yang menghimpun dana dari masyarakat dalam bentuk simpanan dan menyalurkannya ke masyarakat dalam bentuk kredit dan/atau bentuk lainnya dalam rangka meningkatkan taraf hidup rakyat banyak. Bank menghimpun dana masyarakat kemudian menyalurkan dananya kepada masyarakat dengan tujuan untuk mendorong peningkatan taraf hidup rakyat banyak. Dua fungsi pokok bank yaitu menghimpun dana masyarakat dan menyalurkan dana kepada masyarakat.

Bank syariah memiliki sistem operasional yang berbeda dengan bank konvensional. Bank syariah memberikan layanan bebas bunga kepada para nasabahnya. Sistem operasional bank syariah, pembayaran dan penarikan bunga dilarang dalam semua bentuk transaksi. Bank syariah tidak mengenal sistem bunga, baik bunga yang diperoleh dari nasabah yang meminjam uang atau bunga yang dibayar kepada penyimpan dana di bank syariah.

Perbankan syariah adalah segala sesuatu yang menyangkut tentang bank syariah dan unit usaha syariah, mencakup kelembangaan, kegiatan usaha serta cara dan proses dalam melaksanakan kegiatan usahanya. Bank syariah memiliki fungsi menghimpun dana dari masyarakat dalam bentuk titipan dan investasi dari pihak pemilik dana. Fungsi lainnya ialah menyalurkan dana kepada pihak lain yang membutuhkan dana dalam bentuk jual beli maupun kerja sama usaha.

Bank syariah sebagai lembaga intermediasi antara pihak investor yang menginvestasikan dananya dibank kemudian selanjutnya bank syariah menyalurkan dananya kepada pihak lain yang membutuhkan dana. Investor yang menempatkan dananya akan mendapatkan imbalan dari pihak bank dalam bentuk lainnya yang disahkan dalam syariah Islam. Bank syariah menyalurkan dananya kepada pihak yang membutuhkan pada umumnya dalam akad jual beli dan kerja sama usaha. Imbalan diperoleh dalam margin keuntungan, bentuk bagi usaha, dan/atau bentuk lainnya sesuai dengan syariah Islam.

Bank syariah merupakan bank yang kegiatannya mengacu pada hukum Islam, dan dalam kegiatannya tidak membebankan bunga maupun tidak membayar bunga kepada nasabah. Imbalan yang diterima oleh bank syariah maupun yang dibayarkan kepada nasabah tergantung dari akad dan perjanjian antara nasabah dan bank. Perjanjian (akad) yang terdapat di perbankan syariah harus tunduk pada syarat dan rukun akad sebagaimana diatur dalam syariah Islam.

Menurut Ma'arif dan Tanjung (2003:119) antrian adalah situasi barisan tunggu dimana jumlah kesatuan fisik (pendatang) sedang berusaha untuk menerima pelayanan dari fasilitas terbatas (pemberi pelayanan) sehingga pendatang harus menunggu beberapa waktu dalam barisan agar dilayani.Antrian timbul disebabkan oleh kebutuhan akan layanan melebihi kemampuan pelayanan atau fasilitas layanan, sehingga pengguna fasilitas yang tiba tidak bisa segera mendapat layanan disebabkan kesibukan layanan.

Tujuan dasar teori antrian adalah untuk meminimumkan dua biaya, yaitu biaya langsung penyediaan fasillitas pelayanan dan biaya tidak langsung yang timbul karena para individu harus menunggu untuk dilayani. Bila suatu sistem mempunyai fasilitas pelayanan lebih dari jumlah optimal, ini berarti membutuhkan investasi modal yang berlebihan, tetapi bila jumlahnya kurang dari optimal hasilnya adalah tertundanya pelayanan.

Menurut Heizer dan Render (2006:666) terdapat empat model antrian yang paling sering digunakan dalam sistem operasional perusahaan .Model antrian dapat membantu perusahaan dalam 
mengoptimalisasi pelayanan seperti menentukan waktu pelayanan dan menentukan jumlah saluran antrian. Empat model sistem antrian tersebut adalah sebagai berikut:

1. Satu Antrian Satu Pelayanan (Single Channel Single Phase)

2. Satu Antrian Beberapa Pelayanan Tunggal (Multiple Channel Single Phase)

3. Beberapa Antrian Beberapa Pelayanan Paralel (Multi Channel-Multiphase)

4. Satu Antrian Beberapa Pelayanan Paralel (Single Channel Multiple Phase)

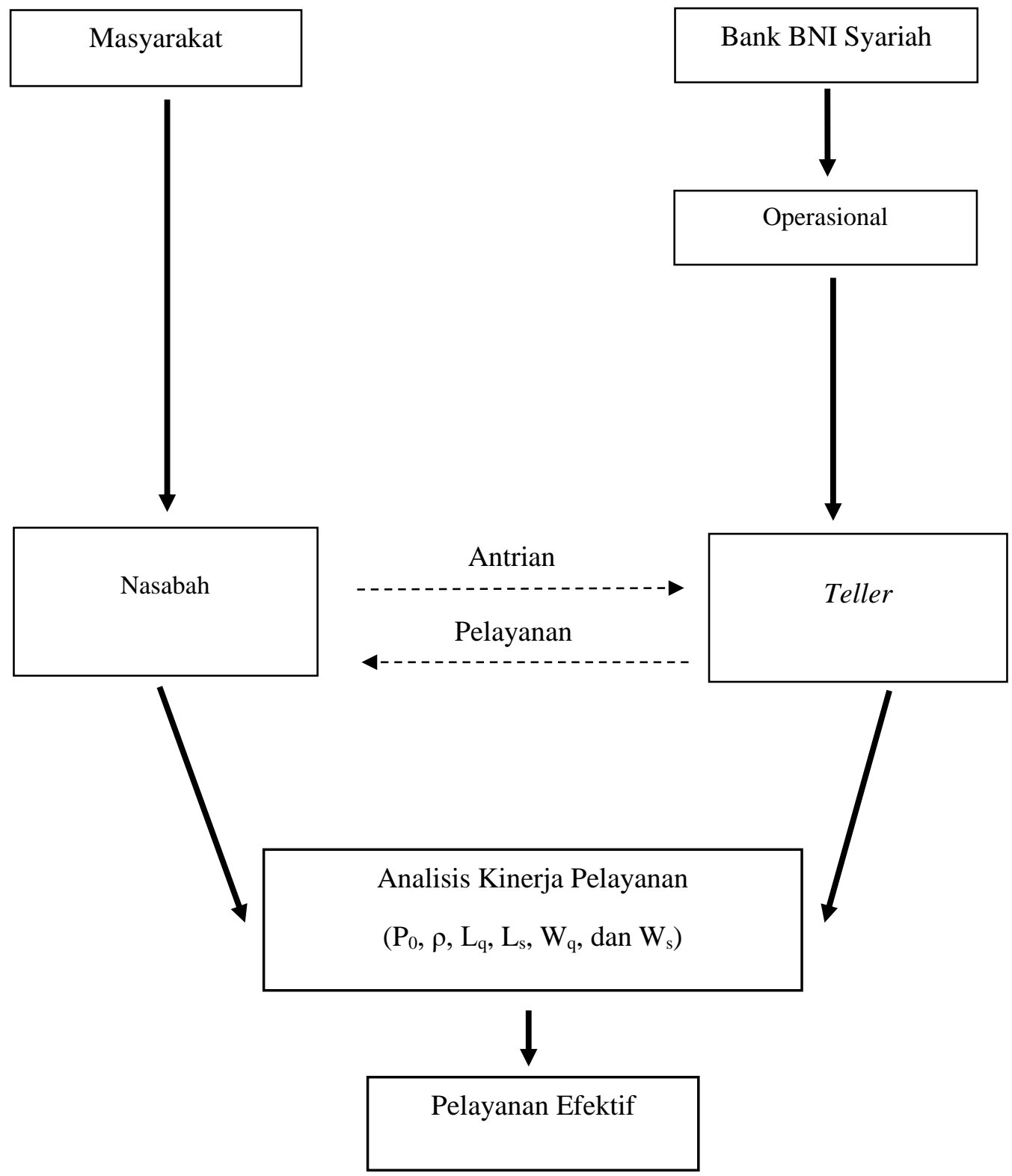

Gambar 1 Kerangka Pemikiran

\section{METODE PENELITIAN}

Pada penelitian ini, peneliti menggunakan penelitian dengan metode deskriptif kuantitatif. Menurut Sugiyono (2015:12) Metode penelitian kuantitatif adalah metode penelitian yang berdasarkan pada filsafat positivisme, digunakan untuk meneliti pada populasi atau sampel tertentu, teknik pengambilan 
sampel pada umumnya dilakukan secara random, pengumpulan data menggunakan instrumen penelitian, analisis data bersifat kuantitati/statistik dengan tujuan untuk menguji hipotesis yang telah ditetapkan.

Obyek dalam penelitian ini adalah Bank BNI Syariah Cabang Kota Palu. Alasan dipilihnya Bank BNI Syariah sebagai obyek penelitian adalah karna satu-satunya Bank BNI syariah yang memiliki cabang dikota Palu dan memiliki antrian pengunjung setiap harinya. Cara untuk memudahkan peneliti dalam melakukan observasi terhadap lokasi antrian maka lokasi penelitian adalah di Jalan Prof. Moh. Yamin pada wilayah opersional Bank BNI Syariah yang berada dekat dengan kampus Universitas Tadulako. Populasi dalam penelitian ini adalah seluruh pengunjung atau nasabah Bank BNI Syariah yang ingin melakukan transaksi pada teller yang tersedia, oleh karena itu, populasi dalam penelitian ini adalah populasi tidak terbatas (infinite) yang tidak diketahui jumlahnya. Sampel dalam penelitian ini adalah seluruh nasabah yang ingin melakukan transaksi pada teller baik ituberupa transaksi tarik tunai dan setor tunai yang berhubungan langsung dengan pihak teller.

Jumlah sampel yang ditarik dalam penelitian ini adalah tidak ditentukan jumlahnya hal ini berdasarkan pada teknik penarikan sampel nonprobability sampling, akan tetapi ditentukan waktu pengamatan selama 1 bulan pengamatan atau 24 hari jam kerja.

1. Sampel berupa orang atau nasabah yang datang ke Bank BNI Syariah untuk melakukan transaksi pada teller pelayanan baik itu setor tunai dan penarikan tunai.

2. Waktu penelitian yang dilakukan adalah terbagi dua sesi yaitu dimulai pukul 08.00-12.00 dan 13.00-16.00.

Data yang digunakan dalam penelitian ini berupa data kedatangan nasabah Bank BNI Syariah per satuan waktu, dan data tingkat pelayanan rata-rata persatuan waktu. Data kualitatif yang digunakan dalam penelitian ini seperti data hasil wawancara, dengan pihak HRD (Human Resource Development), kepala bagian customer services dan security bank, baik keterangan mengenai gambaran umum perusahaan dan keterangan lain yang berhubungan dengan antrian dan pelayanan teller pada Bank BNI Syariah.

Data primer dalam penelitian ini adalah data-data yang diperoleh lansung dari hasil observasi pada obyek penelitian dan wawancara dengan narasumber terkait dengan obyek penelitian data kedatangan dan tingkat pelayanan per satuan waktu dan data pelayanan pada Bank BNI Syariah. Data sekunder dalam penelitian ini diperoleh dari hasil studi pustaka dan pencarian terhadap literatur terkait dengan tema penelitian seperti penelitian-penelitian terdahulu dan hasil penelitian kepustakaan.

Observasi dalam penelitian ini dilakukan dengan mengumpulkan data kedatangan pelayanan Bank BNI Syariah yang dicatat dalam lembar kerja. Wawancara, yaitu dengan melakukan tanya jawab lansung kepada pihak yang dianggap mampu memberi informasi terkait dengan masalah yang akan diteliti. Wawancara, yaitu dengan melakukan tanya jawab lansung kepada pihak yang dianggap mampu memberi informasi terkait dengan masalah yang akan diteliti.

\section{Metode Analisis Untuk Masalah Pertama}

1. Melihat kembali struktur dasar antrian yang diterapkan pada teller pelayanan nasabah Bank BNI Syariah kemudian dicocokan dengan struktur antrian dalam landasan teori.

2. Melakukan analisis karakteristik kedatangan pelanggan, dalam hal ini adalah nasabah yang dijelaskan lebih lanjut berdasarkan ukuran populasinya, distribusi kedatangan dan perilaku kedatangan.

3. Melakukan analisa karakteristik antrian yang dijelaskan lebih lanjut berdasarkan ukurannya, banyaknya garis tunggu antian dan disiplin antrian.

4. Melakukan analisis karakteristik fasilitas pelayanan yang dijelaskan lebih lanjut berdasarkan konfigurasi sistem pelayanan dan distribusi pelayanan.

\section{Metode Analisis Untuk Masalah Kedua}

Jumlah teler yang efektif harus ditempatkan pada loket pelayanannasabah Bank BNI Syariah Cabang Palu dapat dihitung dengan membandingkan hasil perhitungan kinerja antrian dari masingmasing percobaan. Percobaan dilakukan dengan menghitung kinerja dari sistem antrian Bank BNI Syariah dengan menggunakan 1 kasir, 2 kasir, 3 kasir, dan 4 kasir. Hasil perhitungan kinerja antrian 
yang terbaik merupakan jawaban dari permasalahan ini. Beberapa yang diperhitungkan dalam mengukur kinerja suatu antrian yakni $\mathrm{P}_{0}, \rho, \mathrm{L}_{\mathrm{s}}, \mathrm{L}_{\mathrm{q}}, \mathrm{W}_{\mathrm{q}}$, dan $\mathrm{W}_{\mathrm{s}}$ sebagai berikut:

Probabilitas 0 pelanggan dalam hal ini adalah nasabah dalam sistem $\left(\mathrm{P}_{0}\right)$ :

$$
\mathbf{P}_{\mathbf{0}}=\mathbf{1}-\frac{\lambda}{\mu}
$$

Tingkat utilitas atau kesibukan teller:

$$
\boldsymbol{\rho}=\frac{\lambda}{\mu}
$$

Jumlah pelanggan rata-rata dalam antrian $\left(\mathrm{L}_{\mathrm{s}}\right)$ :

$$
\mathbf{L}_{\mathbf{s}}=\frac{\lambda}{\mu-\lambda}
$$

Jumlah pelanggan rata-rata dalam sistem $\left(\mathrm{L}_{\mathrm{q}}\right)$ :

$$
\mathbf{L}_{\mathbf{q}}=\frac{\lambda^{2}}{\mu(\mu-\lambda)}
$$

Waktu rata-rata menunggu dalam antrian $\left(\mathrm{W}_{\mathrm{q}}\right)$ :

$$
\mathbf{W}_{\mathbf{q}}=\frac{\lambda}{\mu(\mu-\lambda)}
$$

Waktu rata-rata yang dihabiskan oleh pelanggan untuk menunggu dalam sistem $\left(\mathrm{W}_{\mathrm{s}}\right)$ :

$$
\mathbf{W}_{\mathbf{s}}=\frac{1}{\mu-\lambda}
$$

\section{HASIL DAN PEMBAHASAN}

Pengumpulan data yang di lakukan dalam penelitian ini adalah pengumpulan data melalui metode observasi. Observasi di lakukan langsung pada teller Bank BNI Syariah Cabang Palu yaitu teller 2 dan 3 namun untuk memudahkan teller 2 dan 3 di anggap menjadi teller 1 dan 2.

a. Rata-rata tingkat kedatangan nasabah

Tabel 1 Data Kedatangan Nasabah Bank BNI Syariah Cabang Kota Palu Pada Teller 1

\begin{tabular}{|c|c|c|c|c|}
\hline \multirow{2}{*}{ No } & \multirow{2}{*}{ Hari/Tanggal } & \multicolumn{2}{|c|}{ Waktu Kedatangan } & \multirow{2}{*}{ Jumlah } \\
\cline { 3 - 4 } & & $08.00-12.00$ & $13.00-16.00$ & \\
\hline 1 & Selasa 02 Juli 2018 & 16 & 10 & 26 \\
\hline 2 & Rabu 04 Juli 2018 & 14 & 11 & 25 \\
\hline 3 & Jumat 06 Juli 2018 & 29 & 19 & 48 \\
\hline 4 & Selasa 10 Juli2018 & 28 & 10 & 38 \\
\hline 5 & Kamis 12 Juli 2018 & 11 & 11 & 22 \\
\hline 6 & Senin 16 Juli 2018 & 30 & 21 & 51 \\
\hline 7 & Rabu 18 Juli 2018 & 28 & 17 & 45 \\
\hline 8 & Jumat 20 Juli 2018 & 19 & 25 & 44 \\
\hline
\end{tabular}




\begin{tabular}{|c|c|c|c|c|}
\hline 9 & Selasa 24 Juli 2018 & 37 & 22 & 59 \\
\hline 10 & Kamis 26 Juli 2018 & 16 & 16 & 32 \\
\hline 11 & Senin 30 Juli 2018 & 16 & 19 & 35 \\
\hline \multicolumn{2}{|c|}{ Jumlah } & 244 & 181 & 413 \\
\hline
\end{tabular}

Sumber:Data Pengamatan 2018

Data di atas merupakan data kedatangan untuk teller 1, jumlah hari kerja yang di lakukan adalah sebanyak 11 hari kerja terhitung dari Selasa 02 Juli 2018 hingga 30 Juli 2018.

Tabel 2 Data Kedatangan Nasabah Bank BNI Syariah Cabang Kota Palu Pada Teller 2

\begin{tabular}{|c|c|c|c|c|}
\hline \multirow{2}{*}{ No } & \multirow{2}{*}{ Hari/Tanggal } & \multicolumn{2}{|c|}{ Waktu Kedatangan } & \multirow{2}{*}{ Jumlah } \\
\cline { 3 - 4 } & & $08.00-12.00$ & $13.00-16.00$ & \\
\hline 1 & Selasa 03 Juli 2018 & 24 & 20 & 44 \\
\hline 2 & Kamis 05 Juli 2018 & 31 & 18 & 49 \\
\hline 3 & Senin 09 Juli 2018 & 27 & 19 & 46 \\
\hline 4 & Rabu 11 Juli 2018 & 16 & 21 & 37 \\
\hline 5 & Jumat 13 Juli 2018 & 15 & 17 & 32 \\
\hline 6 & Selasa 17 Juli 2018 & 22 & 20 & 42 \\
\hline 7 & Kamis 19 Juli 2018 & 20 & 16 & 36 \\
\hline 8 & Senin 23 Juli 2018 & 26 & 15 & 41 \\
\hline 9 & Rabu 25 Juli 2018 & 29 & 17 & 46 \\
\hline 10 & Jumat 27 Juli 2018 & 21 & 20 & 41 \\
\hline 11 & Selasa 31 Juli 2018 & 23 & 14 & 37 \\
\hline \multicolumn{2}{|c|}{ Jumlah } & 254 & 197 & 451 \\
\hline
\end{tabular}

Sumber:Data Pengamatan 2018

Data di atas merupkan data kedatangan untuk teller 2, jumlah hari kerja yang di lakukan adalah sebanyak 11 hari kerja, sama seperti jumlah hari kerja pada teller 1, terhitung dari Selasa 03 Juli 2018 hingga Selasa 31 Juli 2018.

Cara untuk menghitung rata-rata tingkat kedatangan nasabah dapat di lakukan dengan cara membagi jumlah kedatangan nasabah dengan jumlah hari pengamatan. Rata-rata tingkat kedatangan nasabah $(\lambda)$ di formulasikan sebagai berikut:

1. Rata-rata tingkat kedatangan pada periode waktu $08.00-12.00$ pada teller 1

Rata-rata tingkat kedatangan $(\lambda)=\frac{\text { Jumlah Kedatangan }}{\text { Jumlah Hari Pengamatan }}$

$$
\begin{aligned}
& =\frac{244 \text { Kedatangan }}{11 \text { Hari }} \\
& =22,18 \text { nasabah } / 4 \mathrm{jam}
\end{aligned}
$$

Kemudian untuk mengetahui rata-rata tingkat kedatangan nasabah per jamnya di bagi dengan 4 jam, maka di dapatkan hasil:

$$
\begin{gathered}
\frac{22,18}{4 \text { jam }} \\
=5,545 \text { nasabah/jam } \\
\text { Dibulatkan }=5 \text { nasabah/jam }
\end{gathered}
$$

2. Rata-rata tingkat pada periode waktu $13.00-16.00$

Rata-rata tingkat kedatangan $(\lambda)=\frac{\text { Jumlah Kedatangan }}{\text { Jumlah Hari Pengamatan }}$

$$
=\frac{181 \text { nasabah }}{11 \text { hari }}
$$




$$
=16,45 \text { nasabah/jam }
$$

Kemudian untuk mengatahui rata-rata tingkat kedatangan nasabah per jamnya di bagi dengan 3 jam, maka di dapatkan hasil:

$$
\begin{gathered}
\frac{16,45}{3} \\
=5,4833 \text { nasabah/jam } \\
\text { Dibulatkan }=5 \text { nasabah/jam }
\end{gathered}
$$

3. Rata-rata tingkat kedatangan pada periode waktu $08.00-12.00$ pada teller 2

$$
\begin{aligned}
\text { Rata-rata tingkat kedatangan }(\lambda)= & \frac{\text { Jumlah Kedatangan }}{\text { Jumlah Hari Pengamatan }} \\
& =\frac{254 \text { Nasabah }}{11 \text { Hari }} \\
& =23,09 \\
\text { Dibulatkan }= & 23,09 \text { nasabah } / 4 \mathrm{jam}
\end{aligned}
$$

Kemudian untuk mengetahui rata-rata tingkat kedatangan nasabah per jamnya di bagi dengan 4 jam, maka di dapatkan hasil:

$$
\begin{gathered}
\frac{23,09}{4} \\
=5,7725 \text { nasabah/jam } \\
\text { Dibulatkan }=6 \text { nasabah/jam }
\end{gathered}
$$

4. Rata-rata tingkat pada periode waktu 13.00-16.00

$$
\begin{aligned}
\text { Rata-rata tingkat kedatangan }(\lambda)= & \frac{\text { Jumlah Kedatangan }}{\text { Jumlah Hari Pengamatan }} \\
& =\frac{197 \text { Nasabah }}{11 \mathrm{Hari}} \\
& =17,90 \text { nasabah } / 3 \mathrm{jam}
\end{aligned}
$$

Kemudian untuk mengetahui rata-rata tingkat kedatangan nasabah per jamnnya di bagi dengan 3 jam, maka di dapatkan hasil:

$$
\begin{gathered}
\frac{17,09 \text { Nasabah }}{3 \mathrm{Jam}} \\
=5,0966
\end{gathered}
$$

Dibulatkan $=5$ nasabah/jam

Berdasarkan perhitungan di atas, dapat di ketahui bahwa rat-rata tingkat kedatangan nasabah di Bank BNI Syariah Cabang Kota Palu memiliki jumlah yang berbeda, dapat di lihat pada tabel di bawah ini:

Tabel 3 Rekapitulasi Rata-Rata Tingkat Kedatangan Per Jam (Orang)

\begin{tabular}{|c|c|c|c|}
\hline \multirow{2}{*}{ Teller } & \multirow{2}{*}{ Periode Waktu } & \multicolumn{2}{|c|}{ Rata-Rata Tingkat Kedatangan } \\
\cline { 3 - 4 } & & Hasil Perhitungan & Dibulatkan \\
\hline \multirow{2}{*}{1} & $08.00-12.00$ & 5,545 & 5 \\
\cline { 2 - 4 } & $13.00-16.00$ & 5,4833 & 5 \\
\hline \multirow{2}{*}{2} & $08.00-12.00$ & 5,7725 & 6 \\
\cline { 2 - 4 } & $13.00-16.00$ & 5,0966 & 5 \\
\hline
\end{tabular}

$$
\text { Sumber:Data Diolah } 2018
$$

b. Rata-rata tingkat pelayanan

Data waktu pelayanan diperoleh dari hasil observasi dengan mencatat lama waktu yang dibutuhkan teller untuk melayani nasabah. Pencatatan dilakukan dengan mengambil 30 nasabah yang datang ke bank, dan diperoleh data sebagai berikut: 
Tabel 4 Data Waktu Pelayanan Nasabah di Teller Bank BNI Syariah Cabang Kota Palu

\begin{tabular}{|c|c|}
\hline Nasabah (Orang) & Waktu Pelayanan (Menit) \\
\hline 1 & 2,21 \\
\hline 2 & 2,46 \\
\hline 3 & 2,53 \\
\hline 4 & 5,38 \\
\hline 5 & 3,01 \\
\hline 6 & 2,31 \\
\hline 7 & 3,58 \\
\hline 8 & 2,4 \\
\hline 9 & 7,47 \\
\hline 10 & 2,58 \\
\hline 11 & 2,36 \\
\hline 12 & 4,46 \\
\hline 13 & 4,41 \\
\hline 14 & 4,2 \\
\hline 15 & 2,03 \\
\hline 16 & 3,24 \\
\hline 17 & 2,57 \\
\hline 18 & 5,34 \\
\hline 19 & 2,34 \\
\hline 20 & 5,03 \\
\hline 21 & 5,1 \\
\hline 22 & 3,05 \\
\hline 23 & 5,11 \\
\hline 24 & 2,25 \\
\hline 25 & 2,29 \\
\hline 26 & 3,1 \\
\hline 27 & 1,37 \\
\hline 28 & 1,34 \\
\hline 29 & 1,45 \\
\hline 30 & 6,12 \\
\hline Jumlah & 101,09 \\
\hline
\end{tabular}

Sumber: Data Diolah 2018

Cara untuk menghitung rata-rata waktu pelayanan nasabah dapat dilakukan dengan formulasi sebagai berikut:

Rata-rata waktu pelayanan $=\frac{\text { Jumlah waktu pelayanan }}{\text { Jumlah nasabah yang di amati }}$

$$
=\frac{101,09}{30}
$$




\section{$=3,3696$ menit}

Rata-rata waktu pelayanan 3,3696 menit maka dapat di tententukan tingkat pelayanan teller terhadap nasabah per jam dengan formulasi sebagai berikut:

Rata-rata tingkat pelayanan $(\mu)=\frac{\text { Jumlah jam pengamatan }}{\text { Rata-rata waktu pelayanan }}$

Berdasarkan formulasi di atas dapat dihitung:

1. Rata-rata tingkat pelayanan pada periode waktu 08.00-12.00

$$
\begin{aligned}
\text { Rata-rata tingkat pelayanan }(\mu)= & \frac{4 \text { jam }}{\text { Rata-rata waktu pelayanan }} \\
& =\frac{240 \text { menit }}{3,3696 \text { menit }} \\
& =71,2250 \text { nasabah } / 4 \mathrm{jam} \\
& =17,75 \text { nasabah } / \mathrm{jam}
\end{aligned}
$$

2. Rata-rata tingkat pelayanan pada periode waktu $13.00-16.00$

$$
\begin{aligned}
\text { Rata-rata tingkat pelayanan }(\mu)= & \frac{3 \mathrm{jam}}{\text { Rata-rata waktu pelayana }} \\
& =\frac{180}{3,3696} \\
& =38,5802 \mathrm{nasabah} / 3 \mathrm{jam} \\
& =13 \text { nasabah } / \mathrm{jam}
\end{aligned}
$$

Berdasarkan perhitungan di atas, dapat diketahui bahwa rata-rata tingkat pelayanan nasabah di Bank BNI Syariah memiliki jumlah yang berbeda, dapat dilihat pada Tabel 5.5.

Tabel 5 Rekapitulasi Rata-Rata Tingkat Pelayanan Per Jam (Orang)

\begin{tabular}{|c|c|c|}
\hline \multirow{2}{*}{ Periode Waktu } & \multicolumn{2}{|c|}{ Rata-Rata tingkat Kedatangan } \\
\cline { 2 - 3 } & Hasil Perhitungan & Dibulatkan \\
\hline $08.00-12.00$ & 17,75 & 17 \\
\hline $13.00-16.00$ & 12,8600 & 13 \\
\hline
\end{tabular}

Sumber: Data Diolah 2018

\section{Hasil Perhitungan Data}

Tabel 6 Kinerja Pelayanan Pada Teller 1

\begin{tabular}{|c|c|c|c|c|c|c|c|}
\hline Teller & Periode Waktu & $\mathrm{P}_{0}$ & $\mathrm{P}$ & $\mathrm{L}_{\mathrm{s}}$ & $\mathrm{W}_{\mathrm{s}}$ & $\mathrm{L}_{\mathrm{q}}$ & $\mathrm{W}_{\mathrm{q}}$ \\
\hline \multirow{2}{*}{1} & $08.00-12.00$ & 0,7058 & 0,2941 & 0,4166 & 0,08 & 0,1225 & 0,0245 \\
\cline { 2 - 8 } & $13.00-16.00$ & 0,6153 & 0,3846 & 0,625 & 0,125 & 0,2403 & 0,0480 \\
\hline
\end{tabular}

Sumber: Data Diolah 2018

Tabel 7 Kinerja Pelayanan Teller 2

\begin{tabular}{|c|c|c|c|c|c|c|c|}
\hline \multirow{2}{*}{ Teller } & Periode Waktu & $\mathrm{P}_{0}$ & $\mathrm{P}$ & $\mathrm{L}_{\mathrm{s}}$ & $\mathrm{W}_{\mathrm{s}}$ & $\mathrm{L}_{\mathrm{q}}$ & $\mathrm{W}_{\mathrm{q}}$ \\
\hline \multirow{2}{*}{2} & $08.00-12.00$ & 0,6470 & 0,3529 & 0,5454 & 0,0909 & 0,1925 & 0,0320 \\
\cline { 2 - 8 } & $13.00-16.00$ & 0,6153 & 0,3846 & 0,625 & 0,125 & 0,2403 & 0,0480 \\
\hline
\end{tabular}

Sumber: Data Diolah 2018 
Untuk melihat perbandingan kinerja pelayanan yang diterapkan pada teller 1 dan 2 penulis merataratakan jumlah kinerja kedua pelayanan, berikut adalah tabelnya.

Tabel 8 Perbandingan Kinerja Pelayanan Teller 1 dan 2 di Bank BNI Syariah Cabang Palu

\begin{tabular}{|c|c|c|c|c|c|c|r|}
\hline Teller & $\begin{array}{c}\text { Periode } \\
\text { Waktu }\end{array}$ & $\mathrm{P}_{0}$ & $\mathrm{P}$ & $\mathrm{L}_{\mathrm{s}}$ & $\mathrm{W}_{\mathrm{s}}$ & $\mathrm{L}_{\mathrm{q}}$ & $\mathrm{W}_{\mathrm{q}}$ \\
\hline 1 & $08.00-16.00$ & 0,6605 & 0,3393 & 0,5208 & 0,1025 & 0,1814 & 0,0362 \\
\hline 2 & $08.00-16.00$ & 0,6311 & 0,3687 & 0,5852 & 0,1079 & 0,2164 & 0,04 \\
\hline
\end{tabular}

Sumber: Data Diolah 2018

\section{PENUTUP}

Berdasarkan perhitungan yang telah diuraikan di atas, penulis dapat menarik kesimpulan sebagai berikut:

1. Desain pelayanan yang diterapkan pada Bank BNI Syariah Cabang Kota Palu adalah sistem antrian jalur ganda (multi-channel queuing system) dengan sistem satu tahap pelayanan (single-phase system), namun untuk perhitungan masing-masing teller di gunakan sistem antrian jalur tunggal (single-channel queuing system) dengan menggunakan satu tahap pelayanan (single-phase system)

2. Distribusi waktu pelayanan yang digunakan adalah distribusi poisson yaitu waktu pelayanan konstan. Konstan yakni pelayanan yang cenderung tetap dan sama di setiap pelanggan dalam hal ini adalah nasabah.

3. Berdasarkan perbandingan perhitungan antara teller 1 dan 2 yang di terapkan pada Bank BNI Syariah Cabang Kota Palu kinerja pelayanan teller tersibuk berada pada teller 2 hal ini di dasarkan pada tingkat kesibukan yang lebih tinggi yaitu 0,3687 atau 36,87\% sedangkan untuk teller 1 yaitu 0,3393 atau 33,93\%, namun untuk pehitungan probabilitas 0 nasabah dalam sistem (P0), jumlah rata-rata nasabah dalam sistem (Ls), jumlah waktu rata-rata yang dihabiskan dalam sistem (Ws), jumlah rata-rata nasabah yang menunggu dalam antrian (Lq) dan jumlah waktu rata-rata yang dihabskan dalam antrian (Wq) memiliki nilai yang sama, berarti dapat disimpulkan bahwa kinerja kedua teller sama dalam pelayanannya.

Adapun saran-saran yang dapat diberikan penulis guna untuk meningkatkan kualitas layanan yang terdapat pada bank sebagai berikut:

1. Bank sebaiknya hanya menggunakan 1 teller sajadalam pelayanannya, hal ini di dasarkan pada tingkat kesibukan yang tidak terlalu besar pada kinerja atau tingkat kesibukan untuk 2 teller ini.

2. Bank harus lebih ramah lagi dalam melayani nasabah yang ingin melakukan transaksi di bank tersebut, hal ini karena Bank BNI Syariah merupakan satu-satunya Bank BNI Syariah di Kota Palu.

\section{REFERENSI}

Haming, M dan Mahmud Nurnajamuddin., 2011, Manajemen Produksi Moderen Operasi Manufaktuf dan Jasa, Bumi Aksara, Jakarta.

Heizer, dan Rander, 2006, Operation Managemen, Edisi 7, Buku 1, Salemba Empat, Jakarta.

Kosasih, Soebarsa, 2009, Manajeman Operasi Internasional. Mitra Wacana Media, Jakarta.

Kotler, Philip dan Kevin Lane Keller, 2009, Manajemen Pemasaran, Edisi 13, Jilid 2, Eelangga, Jakarta.

Undang-Undang RI No. 10/1998 tentang Perbankan 
Vol. 6, No. 1, Januari 2020, 020 - 031

ISSN : 2443-3578 (On Line) / ISSN : 2443-1850 (Print)

Sugiyono, 2015, Metode Penelitian Bisnis (Pendekatan Kuantitatif, Kualitatif dan R\&d), Alfabeta Bandung.

Yamit, Zulian, 2003, Manajemen Kuantitatif Untuk Bisnis (Operations Research), BPFE-Yogyakarta, Yogyakarta. 